\title{
Pituitary Stalk
}

National Cancer Institute

\section{Source}

National Cancer Institute. Pituitary Stalk. NCI Thesaurus. Code C45912.

A hollow, funnel-shaped process of gray matter that connects the posterior lobe of the pituitary gland to the tuber cinereum of the hypothalamus. 